\title{
Oman's Islamic Banking Performance amidst Covid-19 Outbreak: Prospects and Challenges
}

\author{
Muhammad Iman Sastra Mihajat \\ Al Yusr Islamic Bank, Oman Arab Bank, Oman \\ Corresponding email: m.iman.sastra@gmail.com \\ doi http://dx.doi.org/10.22515/shirkah.v6i1.374
}

\begin{tabular}{|c|c|}
\hline ARTICLE INFO & ABSTRACT \\
\hline $\begin{array}{l}\text { Keywords: } \\
\text { Banking Performance; Covid-19 } \\
\text { Outbreak; Islamic Banking } \\
\text { Entities (IBEs); Islamic Banks' } \\
\text { Prospects and Challenges } \\
\text { Article history: } \\
\text { Received: } 08 \text { February } 2021 \\
\text { Revised: } 29 \text { March } 2021 \\
\text { Accepted: 02 April } 2021 \\
\text { Available online: } 03 \text { April } 2021 \\
\text { To cite in APA style: } \\
\text { Mihajat, M. I. S. (2021). Oman's } \\
\text { Islamic Banking Performance } \\
\text { amidst Covid-19 Outbreak: } \\
\text { Prospects and Challenges. } \\
\text { Shirkah: Journal of Economics and } \\
\text { Business, 6(1), 38-51. }\end{array}$ & $\begin{array}{l}\text { Covid-19 pandemic forced Islamic banking in Oman to slow } \\
\text { down and to change strategies adapting to the current } \\
\text { situation. The Covid-19 outbreak has raised various challenges } \\
\text { for Islamic banking. In order to maintain the sustainable } \\
\text { growth of the industry, stakeholders of Islamic banking should } \\
\text { strive collectively to solve these challenges. Nevertheless, } \\
\text { Islamic banking was able to maintain and manage capital and } \\
\text { liquidity buffers. The growth for } 2021 \text { is expected to remain } \\
\text { stable for at least a single-digit growth. However, there would } \\
\text { be asset-quality and profitability pressure for Islamic banks } \\
\text { within the Sultanate of Oman. This paper highlights the } \\
\text { performance of Islamic banking in Oman amid the Covid-19 } \\
\text { outbreak. This paper demonstrates that the industry merely } \\
\text { recorded a single-digit growth compared to the last seven years } \\
\text { at double-digit growth due to the pandemic. The paper further } \\
\text { delineates on the prospects and challenges of Islamic Banks } \\
\text { Entities (IBEs). It also suggests some practical solutions for } \\
\text { survival. This paper contributes to providing an alluded } \\
\text { picture of the current conditions and situation of Islamic banks } \\
\text { in Oman as well as insights to deal with the challenges to } \\
\text { enhancing the banking performances during the Covid-19 } \\
\text { outbreak. }\end{array}$ \\
\hline
\end{tabular}

This work is licensed under a Creative Commons Attribution-NonCommercial 4.0 International License.

\section{Introduction}

Media reports on unpublished Chinese government data uncovered that the Novel Coronavirus or better known as Covid-19 was first identified on 17 November 2019 in Wuhan City of Hubei province, China. At that time, based on the data obtained from the Chinese authorities in the South China Morning Post, at least 266 cases came under medical surveillance (Fanelli \& Piazza, 2020; Zhang et al., 2020). Currently, Covid-19 has spread around the globe and created suffers people worldwide (Ozili, 2020). The 
outbreak resulting in the unknowable economic impact of the persistence and size (Altig et al., 2020). Day by day, the outbreak is evolving and thereby making it more difficult to project the economic outlook than usual (Barua, 2020). The Covid-19 outbreak provides potentials and challenges for the world economy, including the Islamic banking industry (Açikgöz \& Günay, 2020; Dev \& Sengupta, 2020). The restrictions on travel, significant economic disruption from quarantines, full or partial lockdown, a sharp decline in many services sectors, and factory closures are the indicators (Caraka et al., 2020). Hence, an Islamic bank shall provide its hand to the customers helping them to survive during the pandemic.

Oman has the slowest wave speed of Covid-19 spread rate in the Middle East (Badahdah et al., 2020; Khamis et al., 2020). As of 1 April 2020, the Ministry of Health (MOH) of Oman announced the 18 new Covid-19 confirmed cases, totaling the number of Covid-19 in Oman to 210, including 34 recovered, and 1 death. The first death reported was a 72-year-old patient of COVID-19 on April 1, 2020 (Ministry of Health Oman, 2020). On 4 February 2021, the Ministry of Health reported no deaths for four consecutive days that the total Covid-19 cases reached 135,041 cases involving 127,266 recovered (94.2\%) and 1532 deaths (Ministry of Health Oman, 2020).

Addressing the issue of the Covid-19 outbreak in Oman and its potential impacts on the current economic situation, it is necessary to provide a systematic review of literature about this issue. To the best of the author's knowledge, a comprehensive literature review has still been silent on the prospects and challenges of Oman Islamic banks dealing with the Covid-19 outbreak. Hence, this review paper seeks to explore the Covid-19 outbreak's effect on the growth of Islamic Banking in Oman and how Islamic Banking Entities (IBEs) in Oman suffer from the outbreak. Especially while IBEs provide restructuring, rescheduling, refinancing, and postponement of payment to the customers who are affected directly or indirectly by the outbreak. This paper also highlights how Islamic banks maintain the confidence of the customer amid the epidemic situation. Lastly, this paper also offers practical suggestions for Islamic banks to take advantage of the challenging situation by providing a simple and user-friendly technology through contactless payment, system, and process.

\section{Oman's Islamic Banking Growth in 2020}

The financial services industry and Islamic banking in Oman initiated its operation on the basis of the issuance of Royal Decree Number 69 Year 2012 in early 2013, precisely on 6 December 2012. The Royal Decree issuance added six additional articles, 120-126, in the Banking Law of Oman under the new section entitled 'Islamic Banking' (Mubeen et al., 2014). Articles 120-126 cover the legal framework's general provisions, Islamic banking supervision and advisory, the jurisdiction of the Board of Governor of Central 
Bank of Oman (CBO) to set regulations and guidelines and its authority to Islamic windows and license Islamic banks (Mihajat, 2019).

Being the last country in the Middle East to launch Islamic banking and finance, the Islamic banking establishment in Oman for the last Eight years was upheld by the strong regulatory framework designed by the experienced Islamic banking and finance players in the global market and the experts covering all the aspects of Islamic banking (Kumar \& Shehryar, 2017; Mihajat, 2019). This framework is under the Islamic Banking Regulatory Framework of the Central Bank of Oman for fully-fledged Islamic banks and the Islamic windows of the conventional banks licensed to operate in the Sultanate of Oman.

Previously, Oman had two full-fledged Islamic banks namely Bank Nizwa and Alizz Islamic Bank as well as six Islamic windows namely Al Yusr Islamic Banking of Oman Arab Bank, Muzn Islamic Banking of National Bank of Oman, Sohar Islamic Bank, Maysarah Islamic Bank of Bank Dhofar, Meethaq Islamic Banking of Bank Muscat, and Al Hilal Islamic Bank of Bank Al Ahli. However, after the successful merge of Alizz Islamic Bank and Oman Arab Bank in October 2020, Islamic windows in Oman decreased to five windows. The banks remained two full-fledged Islamic banks. Al Yusr Islamic Banking, the Islamic window of Oman Arab Bank merged with Alizz Islamic Bank to become one of the largest Islamic banking entities within Sultanate as a subsidiary of Oman Arab Bank. Whereby, as the parent company of the newly merged company, Oman Arab Bank noting that these two entities have their own Board of Directors and Management. For the case Alizz Islamic Bank, they have their own Sharia Supervisory Board that has no relationship with Oman Arab Bank (Mihajat, 2021).

Islamic banks in Oman is much promising compared to their counterparts even though Oman is the latest country in the Middle East to present Islamic finance and is considered in the infancy stage (Alam \& Al-Amri, 2020; Bilal et al., 2016; Kamarudin et al., 2018). At the end of 2016, the Islamic banks in Oman's total market share reached $10.3 \%$ of the total banking assets in the Sultanate or equivalent to OMR3.1 billion with 71 branches throughout Oman (Fida et al., 2020). Whereby some countries need 20-30 years in order to have an Islamic banking market share of $5 \%$ to $10 \%$ such as Malaysia and Indonesia (Abdullah et al., 2013).

2018 becomes a golden year for Oman Islamic banking. The banking industry was able to significantly improve its profitability to over OMR34 billion or increase by around $76 \%$ over the previous year and was recorded as the fastest-growing Islamic banking market in the GCC region with a growth rate of 14\% (Salih et al., 2019). This tremendous accomplishment was achieved due to the hard work and determination of the Islamic banking stakeholders who joined hand to hand to prove the impossible 
thing become possible (Al-Shiabah \& Ahmed Mohammed, 2020). Moreover, Islamic banking entities are also able to generate assets with a total of OMR4.3 billion representing around $13 \%$ of the banking assets in the Sultanate (Al-Shiabah \& Ahmed Mohammed, 2020). Therefore, it is predicted that the GCC region will continue as driving growth for global Islamic finance assets for the next several years and remain robust with long-term prospects (Salih et al., 2019). However, Islamic banks shall be cautioned against self-comfort and complacency that would jeopardize the pace of the growth for the next 5 years.

The Central Bank of Oman (CBO) issued a bulletin at the end of 2019 reporting Islamic banking entities that have been able to extend the financing to OMR4 billion, a growth of $11 \%$ over the previous year. Total deposits held by Islamic banking entities recorded an increase by 10.3\% to OMR3.6 billion, as at end-December 2019, the total assets of Islamic banking entities increased to OMR4.9 billion in part due to learning from the experiences from different jurisdictions. CBO does not allow the IBEs to use the contract of bay' al-inah and Tawarruq in their products since they are still being debated among several Islamic economists.

Table 1: Financial Ratios for Islamic Banks in Oman (2016-2020) in millions OMR

\begin{tabular}{llllll}
\hline & $\begin{array}{l}\text { December } \\
\mathbf{2 0 1 6}\end{array}$ & $\begin{array}{l}\text { December } \\
\mathbf{2 0 1 7}\end{array}$ & $\begin{array}{l}\text { December } \\
\mathbf{2 0 1 8}\end{array}$ & $\begin{array}{l}\text { December } \\
\mathbf{2 0 1 9}\end{array}$ & $\begin{array}{l}\text { September } \\
\mathbf{2 0 2 0}\end{array}$ \\
\hline Total assets & 3,100 & 3,570 & 4,300 & 4,900 & 5,000 \\
Total deposits & 2,170 & 2,970 & 3,260 & 3,600 & 3,700 \\
Total financing & 2,420 & 3,030 & 3,604 & 4,000 & 4,200 \\
Islamic banking & $10.3 \%$ & $12.9 \%$ & $13 \%$ & $13,9 \%$ & $14 \%$ \\
market share & & & & & \\
\hline
\end{tabular}

Source: Mihajat (2021).

By 2020, Islamic banking entities in Oman had been predicted to set every other record of remarkable achievement for over the subsequent five years as one of the quickest developing Islamic banking industry globally (Alshubiri et al., 2020). However, the year 2020 becomes the toughest time for the Islamic banking sector to keep up the growth and the slowest growth for the Islamic banking sector in Oman to maintain the growth amid the Covid-19 outbreak (Al-Shiabah \& Ahmed Mohammed, 2020; El Hayek et al., 2020). This single-digit for the last seven years was the first time in the history of Islamic banking in Oman (Al Amri \& Marey-Pérez, 2020). At the end of September 2020, Islamic banking entities only provided financing of OMR 4.3 billion, recording a growth of $6.7 \%$ in the course of the most recent year. Total deposits of Islamic banks and windows increased by $7.7 \%$ to OMR 3.7 billion. While the total assets of Islamic banking entities reached OMR 5 billion and constituted about $14 \%$ of the national banking market share. 
On the profitability side, Oman's Islamic banking sector in 2018 had been able to significantly improve the growth to $76 \%$ compared to the previous year to over OMR 34 million (Tarawneh, 2006). Specifically, 2020 was the hardest time for the Islamic banking sector to keep up the growth in the midst of the Covid-19. CBO in this case initiates with concerned parties to create Islamic Banking Deposit Insurance Scheme (IBDIS) that is expected to cover deposits and investment accounts offered by Islamic banking entities. Likewise, $\mathrm{CBO}$ has been able to finish the groundwork to offer Islamic liquidity management solutions to Islamic banking entities that not only establish standing liquidity facilities and lender of last resort but also provide remunerative deposit account with the Central Bank.

Before the Covid-19 outbreak spreading throughout the globe, the Islamic banking entities in Oman expected to proceed a record of momentous achievement over the next five years (Salim \& Bilal, 2016; Singh \& Fida, 2015). However, notwithstanding the big challenge due to the outbreak, IBEs in the Sultanate encountered a lack of awareness about Islamic banking transactions and activities, insufficient liquidity instruments in the Islamic money market, limited supply of qualified human capital in Islamic finance, and lack of sukuk issuance and its availability in the secondary market (Mihajat, 2018; Riffai et al., 2012; Salim \& Al Ani, 2015). Stakeholders of Islamic banking should address these challenges collectively in order to achieve sustainable growth of the industry (AlGhassani et al., 2017). Specifically for shariah matters, the major players in the IBEs need to incorporate sharia governance in good corporate governance framework (Mihajat, 2019).

\section{The Covid-19 Impact on the SME Sector and Islamic Bank}

The arrival of Covid-19 in Oman, nearly fourteen months after its detection and announcement triggered containment measures; the pandemic is viewed as one of the most exceedingly awful global monetary crises in the modern era, which are having a large economic impact (Cao, 2021; Hidayat, 2020). The Covid-19 pandemic in the last year triggered a large economic impact greater than the global financial crisis in 2008. During the subprime mortgage crisis in 2008, it affected financial institutions that linked to the Collateralized Debt Obligations (CDOs). While during the Covid-19, economic harm caused by the pandemic hits global economic in which the world needs years to recuperate.

Consequently, the Covid-19 impact provoked supply disruption and demand shocks around the globe will have worldwide repercussions. Accordingly, Boone (2020) recognizes at least three main channels through which these measures globally spillover. They are supply, demand, and confidence. The supply deals with the significant disruptions in the global supply chain, cutbacks in many service sector 
activities, and factory closures. Demand is a decline in education services, entertainment and leisure services, and business travel and tourism. Lastly, confidence is the uncertainty leading to delayed or foregone investment, reduced or delayed consumption of goods and services.

The Covid-19 pandemic, via containment measures and the transmission channel has been general comprehensive, intercontinental and inter-sectorial that has sharply slowed economic and business activities (Caraka et al., 2020). The damage incurred and sectors and caused a tremendous loss, not only in China but also in its economic partners (Açikgöz \& Günay, 2020; Hidayat, 2020). All severely affected consumer and financial market confidence. However, predicted sectors experiencing the biggest and the greatest loss is small and medium enterprises (SMEs), not only in Oman but also all countries that are directly or indirectly affected by the pandemic (Affandi et al., 2020; Shafi et al., 2020).

It is undeniable that everybody is aware of the strategic importance of SMEs to the economic development of the country (Jena et al., 2018; Prastiwi \& Rohimat, 2020). Besides, the contribution of SMEs in Oman is only 15\% to the national GDP compare to the contribution of SMEs in developing countries between 40 to 60\% (Al Badi, 2018; AlMaimani \& Johari, 2015). According to the data published by the Public Authority for SME Development, the number of SMEs in Oman is increasing year by year reaching 34,894 establishments by the end of June 2018 compared to 31,835 at the end of 2017 (Oman Observer, 2020). Whereby most of the SMEs are registered in the Muscat Governorate. According to Central Bank of Oman (2020), the rate of SMEs in Muslim countries per 1000 population is 53.2 enterprises, more than twice the global rate of 25.2 enterprises per 1000 population.

In many countries, amid the Covid-19 outbreak, SMEs sector is suffering from shrinking economic activities due to the large scale of confinement imposed by law. They are fighting for survival in order to find another resource to manage capital expenditure and operating expenses such as salaries, rent, new marketing strategy, as well as their obligation with financial institutions (Shafi et al., 2020). Therefore, many SMEs tried to cut the expenses by laying off the workers that will lead not only to economic crisis but also to a severe social crisis. This will lead to disastrous consequences in most countries that have limited resources and feeble economic activity. Economists estimated that 25 million jobs could be lost worldwide amid the Covid-19 (Al Amri \& Marey-Pérez, 2020).

Based on a poll conducted during the peak of the pandemic, a group of researchers from Tsinghua University, China, uncovered that a third of respondents of SMEs cannot carry on for over one month during the pandemic. It was revealed that a third of the sample admitted that they could not carry on for more than two months. Unfortunately, 
only $10 \%$ of respondents can survive for six months or more. Therefore, as per the guidelines issued by the Central Bank of Oman (CBO) through its circular BSD/CB/2020/1 dated March 18, 2020, CBO allowed for financial institutions (banking sector and financing leasing companies, conventional and Islamic) to overcome the prevailing economic conditions by deferring the financing installment, rental as well profit for customers who are affected from the Covid-19 up to 6 months period for SME customers. As such, SME customers shall take advantages of the above CBO circular so that they can survive longer than only 1-6 months period. They are few benefits that can be seen from the circular such as helping business continuity and jobs sustainability and to overcome the ensuing impacts of unemployment and large-scale bankruptcy. In addition, Islamic bank plays the role with the support from the government and concerned authorities to provide Covid-19 financing programs that encourage the financial institutions to expand financing during the outbreak.

According to Mihajat (2021), during 2020, Islamic banking entities play critical part in assisting the government to strengthening economic activities within the Sultanate amid the pandemic, including (1) deferring monthly installments for 6-12 months including short term working capital facilities and term finance facilities (based on the contract of Wakalah Investment, Running Musharakah, Musharakah Mutanaqishah, Balance fund transfer with Ijarah sale and lease back or Musharakah Mutanaqishah), (2) providing a grace period or repayment holiday for SMEs's customers for 6-9 months (without increasing the profit even one single ceiling), (3) providing extension of total number of installment repayments for term finance facilities based on the request of customer, (4) providing rescheduling and restructuring of financing for customers who are having overdue (from 30 to 90 days) with Islamic bank as per the request, (5) reducing existing fees of various banking services and abstain from introducing new ones during 2020, (6) distributing the charity funds to charity organizations within the Sultanate, (7) distributing major percentage in CSR fund to distribute to the individuals who are influenced by the pandemic and assisting the government in handling and fighting the COVID-19 by contributing donations to an account designated by the Ministry of Health, and (8) supporting the laid-off and who lose their jobs during the Covid-19 for different reasons by contributing to the Job Security Fund initiated by Government of Oman through the issuance of Royal Decree No 82/2020. Moreover, according to Arabian Business (2020), the Central Bank of Oman was poured out OMR 8 billion ( $\$ 20$ billion) economic stimulus package. The incentive package proposed to handle the pandemic and to fight the effect of Covid-19 on the local economy as additional liquidity to the country's financial institutions. 


\section{Prospects and Challenges}

The year 2020 becomes a very much challenging time for the Islamic banking sector to maintain growth. Islamic banking entities suffer from a significantly reduction in revenue and credit growth from double-digit to single-digit for the last eight years due to earning shock from the oil price drop and the Covid-19 outbreak. Since oil prices remain the top factor for the development of the Islamic banking and finance industry in the Sultanate, 2021 will yet be another interesting year for the industry with expectations of an upward direction in the growth of the Islamic banking and finance industry to attract more investors and customers through the presentation of innovative product structures and instruments. 2019 has been an intriguing year as the political environment and volatility of the oil prices especially after the drone attack on Saudi Arabia's largest oil field and oil infrastructure. Abqaiq sidelined is the world's biggest crude processing facility with a total of 5.7 million barrels per day (BPD) of oil production (Reuters, 2019).

The main issues in 2020 will continue in 2021 such as lower profit rates, lower business volumes, and higher financing impairment charges as a result of lower oil prices and the outbreak, Islamic banking entities in the Sultanate will be focusing on saving assets quality rather than business expansion. This is due to Islamic banks in Oman are typically having a major proportion of exposure in real estate and not able to charge late payment fees, they will see a greater effect on asset-quality indicators. That is why the pandemic will halt the growth of Islamic bank this year by only single-digit growth if the oil prices still decline below USD 50, real-estate corrections and low demand, and drop in vital non-oil economic sectors such as tourism putting pressure on Islamic banks' earnings (Mihajat, 2021).

It is predicted that 2021 will be the hardest challenge for the Islamic banking sector in Oman and the GCC as the coronavirus pandemic devastating the energy demand because Oman is one of GCC countries that expose to gas and oil exports. It is predicted that the most significant channel through which effects of the coronavirus are felt is the decline in the prices of petroleum-related products. Although the trade war between Saudi and Russia is another factor that tumbling the oil price surpassed $30 \%$ on Monday, March 30, 2020. Since the Gulf War in 1991, it was the sharpest single-day decline. Goldman Sachs analysts predicted that the oil price could tumble further as low as $\$ 20$ per barrel (International Energy Agency, 2020). Covid-19 was likely the main important factor, to a great extent on the significant drop in demand from China. The demand for China's oil accounted for $14 \%$ of the global demand while China's growth in oil demand accounts for more than $80 \%$ of global growth (International Energy Agency, 2020). As such has made wary inclination in the Islamic finance sector. The oil prices stay the fundamental factor for the growth of Islamic finance and banking in the 
region.

Nonetheless, notwithstanding the severe challenge over the outbreak, the Islamic Banking Entities in the Sultanate encountered many issues and challenges, for instance, the lack of awareness about Islamic banking transactions and activities, limited supply of qualified human capital in Islamic finance, insufficient liquidity instruments in the Islamic money market, and lack of Sukuk issuance and its availability in the secondary market. Stakeholders of Islamic banking should encounter these challenges together to achieve the expected growth of the industry. Especially in the area of Sharia matters, the major players in the IBEs need to incorporate Sharia governance in their good corporate governance framework (Mihajat, 2021).

Another challenge encountered by Islamic banks is the way to digitalize the payments and the services. Particularly during the outbreak, banknotes may facilitate virus transmission, in which some central banks disinfect their banknotes in order to stop the virus spread. Therefore, World Health Organization recommends the use of contactless payment. Consequently, Islamic banks can rely on digital technologies and minimize the use of physical branches. In order to adapt them to the new market reality until the Covid-19 outbreak ends, Islamic banking entities should take advantage of this opportunity to experience a new operating business model. In fact that Islamic banks can modify the Covid-19 crisis from a challenge to become an opportunity by transforming the business process through the simplification of technology and user friendly. As we are aware that we are already seeing these changes from the previous years with examples such as all-in-one application for taxi, car rent, food delivery, ticketing, hotel booking, and fintech.

And finally, in the year 2021 Islamic banks should be able to evolve with the new business model, transform the processes, adapt the organization, and finally conduct the radical changes. The Covid-19 has brought a lot of innovation on digital payments on how Islamic banks can simplify the technology. Today, amid the coronavirus pandemic, digital payments is one of the most important elements such as cardless onetouch payment systems using barcodes in smartphones or using a card with contactless payment for just tap it in POS machine.

Despite all the challenges, we still expect the industry will continue to grow although it is lower than expected. Especially for new markets (such as in Africa) are gearing up to embrace Islamic banking and finance with their new unique regulation as per their jurisdiction, new players, and new more innovative products that suitable for post-Covid-19 era so that they will be able to tackle the upcoming challenging year. The strategy should embrace the current market trend, while new products should be suitable for their customers, not only for the purpose of the growth of the industry but 
also to support the economy of the country. Therefore, amid the outbreak situation, Islamic bank should update their strategy, adapt their budget, and plan for the worst case.

\section{Conclusion}

The Covid-19 flare-ups are spreading and increasing day by day that makes the projection of the economic outlook capricious. The unprecedented circumstance takes a critical impact to derail the potential of future growth of the global economy. The economic and financial will experience the greatest loss of disruption from quarantine, restrictions on travel, full lockdown or partial lockdown, factory closures and a sharp decrease in many services sectors and now are in the eye of the storm. The situation forced Islamic banking entities to slow down the growth. However, Islamic banking entities are still able to maintain and manage capital buffers and liquidity so that the growth for 2021 is expected to remain stable for at least one-single digit growth. The sector suffering more from the Covid-19 pandemic is the SMEs sector from shrinking economic activities due to the enormous scope of confinement imposed by law in many countries. SME currently tries to find their way in order to survive by maximizing the available resources to manage their business activities so that far from collapse.

As for the SMEs, cutting the expenses by laying off the workers or asking them to take unpaid leave were done by many small and medium companies because of the large-scale confinement. This will lead to economic disastrous in many countries that have limited resources and weak economic activity. In this case, Islamic banking entities try to assist the sector by providing rescheduling, restructuring, refinancing, and postponement of payment so that the SMEs are able to survive amid the pandemic. Therefore, it is the ideal opportunity for the Islamic bank to take a vital role. The Islamic banking entities should be able to evolve the business model, transform the processes, adapt the organization, and in the end conduct the radical breakthrough amid the pandemic. Previously, the discussion deals with innovation on digital payments on how Islamic banks can simplify the technology. Today, amid the coronavirus pandemic, digital payment is a must. In Oman, currently, cardless one-touch payment systems using barcodes in smartphones are used.

\section{Author's Declaration}

The author made substantial contributions to the conception and design of the study. The author took responsibility for data analysis, interpretation and discussion of results. The author read and approved the final manuscript.

\section{ORCID}

Muhammad Iman Sastra Mihajat (D) https://orcid.org/0000-0001-6763-6298 


\section{References}

Abdullah, W. A. W., Percy, M., \& Stewart, J. (2013). Shari'ah disclosures in Malaysian and Indonesian Islamic banks: The Shari' ah governance system. Journal of Islamic Accounting and Business Research, 4(2), 100-131. https://doi.org/10.1108/JIABR-102012-0063

Açikgöz, Ö., \& Günay, A. (2020). The early impact of the Covid-19 pandemic on the global and Turkish economy. Turkish Journal of Medical Sciences, 50(1), 520-526.

Affandi, A., Sarwani, A. S., Erlangga, H., Siagian, A. O., Purwanto, A., Effendy, A. A., Sunarsi, D., Wicaksono, W., Suyatin, E. A., \& Wahyitno, C. D. M. (2020). Optimization of MSMEs Empowerment in Facing Competition in the Global Market during the COVID-19 Pandemic Time. Systematic Reviews in Pharmacy, 11(11), 1506-1515.

Al-Ghassani, A. M., Al-Lawati, A. M., \& Ananda, S. (2017). BAnking Sector in Oman: Strategic Isuue, Challenges and Future Scenarios. College of Banking and Financial Studies.

Al-Shiabah, A. A. A. Bin, \& Ahmed Mohammed, A. (2020). Measuring the Financial Performance of Islamic Banks in Oman Comparative Study". Journal of Islamic Banking \& Finance, 37(3), 1-15.

Al Amri, T., \& Marey-Pérez, M. (2020). Impact of Covid-19 on Oman's Construction Industry. Technium Social Science, 9(1), 661-670.

Al Badi, K. S. (2018). The impact of marketing mix on the competitive advantage of the SME sector in the Al Buraimi Governorate in Oman. SAGE Open, 8(3), 2158244018800838.

Alam, N., \& Al-Amri, H. A. (2020). Service quality perception and customer satisfaction in Islamic banks of Oman. The Journal of Asian Finance, Economics, and Business, 7(9), 499-504.

AlMaimani, J., \& Johari, F. B. (2015). Enhancing active participation of SMEs and Islamic Banks towards economic diversification in Oman. Procedia Economics and Finance, 31, 677-688.

Alshubiri, F. N., Tawfik, O. I., \& Jamil, S. A. (2020). Impact of petroleum and nonpetroleum indices on financial development in Oman. Financial Innovation, 6(1), $1-22$.

Altig, D., Baker, S., Barrero, J. M., Bloom, N., Bunn, P., Chen, S., Davis, S. J., Leather, J., Meyer, B., \& Mihaylov, E. (2020). Economic uncertainty before and during the Covid-19 pandemic. Journal of Public Economics, 19(1), 104-120.

Arabian Business, (2020). Oman unveils \$20bn economic stimulus as virus burden looms, retrieved April 4 2020, from https://www.arabianbusiness.com/bankingfinance/443231-oman-unveils-20bn-economic-stimulus-as-virus-burden-looms

Badahdah, A. M., Khamis, F., \& Al Mahyijari, N. (2020). The psychological well-being of physicians during COVID-19 outbreak in Oman. Psychiatry Research, 28(9), 113-123.

Barua, S. (2020). Understanding Coronanomics: The economic implications of the coronavirus 
(COVID-19) pandemic. Available at SSRN: http://dx.doi.org/10.2139/ssrn.3566477

Bilal, Z. O., Durrah, O. M., \& Atiya, T. M. (2016). Comparative Study on Performance of Islamic Banks and Conventional Banks: Evidence from Oman. International Journal of Economics and Financial Issues, 6(4), 1-23.

Boone, L. (2020). Tackling the fallout from COVID-19, Richard Baldwin and Beatrice Weder di Mauro (Ed.) Economics in the Time of COVID-19. CEPR Press, 37-44.

Cao, T. (2021). The Study of Factors on the Small and Medium Enterprises' Adoption of Mobile Payment: Implications for the COVID-19 Era. Frontiers in Public Health, 9,122 .

Caraka, R. E., Lee, Y., Kurniawan, R., Herliansyah, R., Kaban, P. A., Nasution, B. I., Gio, P. U., Chen, R. C., Toharudin, T., \& Pardamean, B. (2020). Impact of COVID19 large scale restriction on environment and economy in Indonesia. Global Journal of Environmental Science and Management, 6(Special Issue (Covid-19)), 6584.

Central Bank of Oman. (2020). Monthly Statistical Bulletin February 2020, retrieved April 22020 from https://cbo.gov.om/report/MonthlyBulletins/107

Dev, S. M., \& Sengupta, R. (2020). Covid-19: Impact on the Indian economy. Indira Gandhi Institute of Development Research, Mumbai, April.

El Hayek, S., Cheaito, M. A., Nofal, M., Abdelrahman, D., Adra, A., Al Shamli, S., AlHarthi, M., AlNuaimi, N., Aroui, C., \& Bensid, L. (2020). Geriatric mental health and COVID-19: An eye-opener to the situation of the Arab countries in the Middle East and North Africa Region. The American Journal of Geriatric Psychiatry, 28(10), 1058-1069. https://doi.org/10.1016/j.jagp.2020.05.009

Fanelli, D., \& Piazza, F. (2020). Analysis and forecast of COVID-19 spreading in China, Italy and France. Chaos, Solitons \& Fractals, May, 134:109761._doi: 10.1016/j.chaos.2020.109761.

Fida, B. A., Ahmed, U., Al-Balushi, Y., \& Singh, D. (2020). Impact of service quality on customer loyalty and customer satisfaction in islamic banks in the Sultanate of Oman. Sage Open, 10(2), 2158244020919517.

Hidayat, S. E. (2020). Islamic Economy in ASEAN Countries During the Covid-19 Era. Retrieved at November 2020 from kneks.go.id.

International Energy Agency. (2020). Oil Market Report - March 2020. Retrieved April 32020 from https://www.iea.org/reports/oil-market-report-march-2020

Jena, N. R., Thatte, L. R., \& Ket, V. G. (2018). Performance of the micro, small and medium enterprises (MSMEs) manufacturing sector in select states in India: The concept of MSME Manufacturing Business Facilitator (MSME-MBF) Index. Academy of Entrepreneurship Journal, 24(1), 1-22.

Kamarudin, F., Sufian, F., Nassir, A. M., Anwar, N. A. M., Ramli, N. A., Tan, K. M., \& Hussain, H. I. (2018). Price efficiency on Islamic banks vs. conventional banks in Bahrain, UAE, Kuwait, Oman, Qatar and Saudi Arabia: impact of country governance. International Journal of Monetary Economics and Finance, 11(4), 363383.

Khamis, F., Al Rashidi, B., Al-Zakwani, I., Al Wahaibi, A. H., \& Al Awaidy, S. T. (2020). Epidemiology of COVID-19 infection in Oman: analysis of the first 1304 
cases. Oman Medical Journal, 35(3), e141.

Kumar, V., \& Shehryar, M. (2017). An Evaluation of Islamic Banking at Bank Muscat, Oman. Review of Integrative Business and Economics Research, 6(3), 254-265.

Mihajat, M. I. S. (2018). Shari'a Governance Framework in Islamic Banking in Oman: Issues and Challenges. In The Name of Allah, The Most Beneficent, The Most Merciful, 73.

Mihajat, MIS. (2019). "Shari'ah Governance Framework in IFIs in Oman: Issues and Challenges", Azid, T., Alnodel, A. and Qureshi, M. (Ed.) Research in Corporate and Shari'ah Governance in the Muslim World: Theory and Practice, Emerald. doi: $10.1108 / 9781789730074$

Mihajat, MIS. (2021). Oman's Islamic banking performance in 2020 and outlook for 2021. IFN News, 27th January 2021, pp 24-25.

Ministry of Health, Oman, 2020. Statement No. 35, April 1, 2020. Retrieved April 6 from https://www.moh.gov.om/en/-59

Mubeen, S. A., Kulkarni, N. A., \& Al Hussaini, Y. K. (2014). The future of Islamic banking in Sultanate of Oman. International Journal of Economics and Finance, 6(5), 203-209.

Oman Observer. (2020). Sultanate's Islamic banking sector posts world-leading growth rate. Retrieved April 22020 from https://www.omanobserver.om/sultanates-islamic-banking-sector-posts-world-leading-growth-rate/

Ozili, P. K. (2020). Covid-19 pandemic and economic crisis: The Nigerian experience and structural causes. Journal of Economic and Administrative Sciences, 36(4), 23-35.

Prastiwi, S. K., \& Rohimat, A. M. (2020). Performance of GoFood MSEs Partnership: An Integration of Entrepreneurial Orientation, Marketing Capabilities, and Brand Orientation. Shirkah: Journal of Economics and Business, 5(3), 310-336.

Reuters. (2019). Attacks on Saudi facilities threaten spare oil capacity, price hikes. Retrieved February 72021 from https://www.reuters.com/article/us-saudiaramco-fire-capacity-idUSKBN1VZ0OJ

Riffai, M., Grant, K., \& Edgar, D. (2012). Big TAM in Oman: Exploring the promise of on-line banking, its adoption by customers and the challenges of banking in Oman. International Journal of Information Management, 32(3), 239-250.

Salih, A., Ghecham, M. A., \& Al-Barghouthi, S. (2019). The impact of global financial crisis on conventional and Islamic banks in the GCC countries. International Journal of Finance E Economics, 24(3), 1225-1237.

Salim, B. F., \& Al Ani, M. K. (2015). The Impact of Islamic Banking Challenges and Opportunities on the Market Share: Evidence from Oman. European Journal of Economics, Finance and Administrative Sciences Issue, 76(1), 28-37.

Salim, B. F., \& Bilal, Z. O. (2016). The impact of liquidity management on financial performance in Omani banking sector. International Journal of Accounting, Business and Economic Research, 14(1), 545-565.

Shafi, M., Liu, J., \& Ren, W. (2020). Impact of COVID-19 pandemic on micro, small, and medium-sized Enterprises operating in Pakistan. Research in Globalization, 2, 100018. http://dx.doi.org/10.1016/j.resglo.2020.100018 
Singh, D., \& Fida, B. A. (2015). Technical efficiency and its determinants: An empirical study on banking sector of Oman. Problems and Perspectives in Management, 13(1), 168-175.

Tarawneh, M. (2006). A comparison of financial performance in the banking sector: Some evidence from Omani commercial banks. International Research Journal of Finance and Economics, 3(3), 101-112.

Zhang, S., Wang, Z., Chang, R., Wang, H., Xu, C., Yu, X., Tsamlag, L., Dong, Y., Wang, H., \& Cai, Y. (2020). COVID-19 containment: China provides important lessons for global response. Frontiers of Medicine, 14, 215-219. https://doi.org/10.1007/s11684-020-0766-9. 